\title{
Determination of Boron in hazelnut varieties with the addition of sorbitol by using ICP-OES and ultrasonic nebulization after microwave digestion system
}

\author{
Mustafa S. Dündar $\odot^{*}$, Huseyin Altundag $\odot$ and Gulsah Tunca \\ Sakarya University, Faculty of Arts and Sciences, Department of Chemistry, 54187, \\ Sakarya, Turkiye
}

(Received November 28, 2018; Revised December, 18, 2018; Accepted December 19, 2018)

\begin{abstract}
Boron is an essential nutrient for plants and an essential element for many organisms, but can be toxic to aquatic and terrestrial organisms above certain concentrations. The aim of this research is determining the Boron content of four varieties of Hazelnut (Corylus avellana L.) from Sakarya. Inductively coupled plasma optical emission spectrometry (ICP-OES) with ultrasonic nebulization (USN) was used for the determination of Boron contents. This method is based on microwave digestion system and reduced memory effect of Boron by using sorbitol. Different conditions were optimized for this method. Four hazelnut varieties, eight soil samples and certificated reference material (NIM-GBW10012) were analyzed. The Boron contents were found as 18.27, 28.3, $38.6,17.6 \mathrm{mg} / \mathrm{kg}$ in Kara, Sivri, Delisava and Tombul hazelnut varieties, respectively. And Boron contents of soil samples were between 30.44 to $196.79 \mathrm{mg} / \mathrm{kg}$. The results revealed that the Turkish hazelnut is a good natural source of Boron.
\end{abstract}

Keywords: Boron; microwave digestion; hazelnut; memory effect; ICP-OES; USN. @ 2018 ACG Publications. All rights reserved.

\section{Introduction}

Turkey is generally the origin of hazelnut for cultivated and wild varieties and has suitable ecological conditions for growing up high quality hazelnut varieties. Also, hazelnut is a very important commercial product for Turkey and is widely used in the food industry [1,2]. Hazelnut has a major role in human nutrition due to its special nutrient values such as proteins, carbohydrates, fats, vitamins and minerals $[1,3,4]$. Turkish hazelnut varieties are rich in Boron and can be used as nutritional source for Boron [5]. Boron with $\mathrm{Ca}, \mathrm{P}$ and vitamin $\mathrm{D}$ helps maintaining strong bones [5,6,7,8]. Furthermore Boron is important for immune system, Calcium and Magnesium metabolism, endocrine functions and energy metabolism [5].

In recent years, the role of Boron in human and animal nutrition has increased and importance on the natural and human life has begun to be realized [6]. Plants need Boron for their development but extreme amounts of Boron turn into an herbicide [5,9]. Also extreme amount of Boron is toxic for humans. Daily intake of Boron up to $500 \mathrm{mg}$ may cause nausea, vomiting and diarrhea [5].

\footnotetext{
* Corresponding author; E-mail: dundar@ sakarya.edu.tr ; Phone:+90 26429460 44; Fax:+90 2642955950
} 
The demand for determination of Boron in food and biological samples is increased $[6,10]$. Many methods for determination of Boron are defined in the literature [5, 12]. The use of ICP-OES and ICPMS is developing for determination of Boron and there is no considerable difference between them [9, 11]. However, the instrumental cost and spectral interference of ${ }^{12} \mathrm{C}$ limit the extensive application of ICPMS in Boron analysis, so it makes ICP-OES a preferred technique [9]. ICP-OES with typical pneumatic nebulizer is not sensitive enough to detect Boron when amount of samples is limited and the concentration of Boron is very low. Advantages of USN are more than those of pneumatic nebulizer but USN has not been applied easily to detect Boron due to memory effect. [6].

ICP-OES created a new dimension in Boron determination because of its simplicity, sensitivity and multielement capability [13]. Other methods for mineral analysis are less sensitive to Boron and complicated for chemical sample pretreatment [9].

Many digestion methods were used for different materials to prepare samples; dry digestion, wet digestion and microwave digestion. Dry ashing and acid digestion procedures are reliable, but they have disadvantages as well. Dry ashing procedure needs 2-3 days to digest samples. Acid digestion (3-4 hours) is faster than dry ashing digestion but it is difficult to control the operation [14].

In recent years, microwave digestion method is widely used to prepare samples [9]. Compared to other methods, microwave digestion is not only faster, easier and more reliable but also less dangerous and uses less amount of chemicals [9, 14-16]. It has more accuracy and high recovery [16-19]. Using a closed high-pressure polytetrafluoroethylene (PTFE) vessel in microwave digestion system prevent external contamination and loss of the volatile elements [9, 14, 21, 22]. Furthermore, in the microwave digestion system vessels, temperature, pressure and power are controlled by a computer.

In this work, the aim of using sorbitol is to develop a new method to decrease or overcome memory effect. Boron content of samples is determined by using ICP-OES and USN.

\section{Experimental}

\subsection{Chemicals and Reagents}

$65 \% \mathrm{HNO}_{3}, 30 \% \mathrm{HCl}$, and $30 \% \mathrm{H}_{2} \mathrm{O}_{2}$ used were Suprapur quality (Merck, Darmstadt, Germany). D(-) Sorbitol was analytical-grade (Merck, Darmstadt, Germany). A $10 \mu \mathrm{g} \mathrm{ml}{ }^{-1}$ Boron solution (Spectrascan - Breitlander Gmbh D-59077 Hamm, Germany) was used as standard solution. All glassware and polyethylene bottles were cleaned with $10 \% \mathrm{HNO}_{3}$. Samples were diluted with distilled deionized water (chemical resistivity: $18 \mathrm{M} \Omega \mathrm{cm}^{-1}$ ). Corn flour (NIM-GBW10012, China National Center for Standard Materials, Beijing) was used for certified reference material.

\subsection{Instrumentation}

A Milestone Start D Microwave Digestion System (Via Fatebenefratelli Sorisole, Bergamo, Italy) was used for sample digestion. The samples were nebulized by a U5000A+ ultrasonic nebulizer (CETAC, Omaha, Nebraska, USA). The sample analysis was carried out ICP-OES (Spectro Analytical Instruments $\mathrm{GmbH}$, Germany). Optimization conditions for ICP-OES are displayed in Table 1.

Table 1. ICP-OES Instrument Plasma Conditions

\begin{tabular}{ll}
\hline Plasma Power & $1450 \mathrm{Watt}$ \\
Pump Speed & $30 \mathrm{rpm}$ \\
Coolant Flow & $13.0 \mathrm{~L} / \mathrm{min}$ \\
Auxiliary Flow & $1.0 \mathrm{~L} / \mathrm{min}$ \\
Nebulizer Flow & $0.8 \mathrm{~L} / \mathrm{min}$ \\
\hline
\end{tabular}




\subsection{Sample preparation}

Four varieties of hazelnut were collected from two different districts of Sakarya province. Delisava and Sivri hazelnut varieties were collected from Ferizli, Kara and Tombul hazelnut varieties were collected from Yanıkköy-Sapanca. Hazelnut samples were hulled and powdered. Then powdered hazelnuts were dried 24 hours at $100^{\circ} \mathrm{C}$. Dried samples were stored until the analysis.

The samples (0.5 gram) were accurately weighted into PTFE vessels then $7 \mathrm{ml} \mathrm{HNO}_{3}(65 \%)$ and $1 \mathrm{ml} \mathrm{H}_{2} \mathrm{O}_{2}(30 \%)$ were added. The program in Table 2 was used for microwave digestion. The hazelnut samples and certified reference materials were prepared using this program. After digestion period dissolved samples were transferred into $100 \mathrm{ml}$ flasks followed by addition of $10 \mathrm{ml} 5 \%$ sorbitol solution in each flask and diluted to volume with distilled deionized water.

Table 2. Microwave digestion program applied for hazelnut samples

\begin{tabular}{lllc}
\hline Step & Time & Power & Temperature \\
\hline 1 & $10 \mathrm{~min}$ & 800 watt & $200{ }^{\circ} \mathrm{C}$ \\
2 & $20 \mathrm{~min}$ & 800 wat & $200{ }^{\circ} \mathrm{C}$ \\
\hline
\end{tabular}

Soil samples were also taken for Boron content analysis where hazelnut varieties were cultivated. These samples $(0.5 \mathrm{~g})$ were dried and transferred into PTFE vessels, then $9 \mathrm{ml} \mathrm{HCl}(30 \%)$ and $3 \mathrm{ml} \mathrm{HNO}_{3}$ $(65 \%)$ were added. The program in Table 3 was applied. The same procedures were used for hazelnut samples and applied to Boron analysis. In addition, reagent blank solutions were prepared by using the same procedure.

Table 3. Microwave digestion program applied for soil samples

\begin{tabular}{lllc}
\hline Step & Time & Power & Temperature \\
\hline 1 & 10 min & 800 watt & $200{ }^{\circ} \mathrm{C}$ \\
2 & 15 min & 800 wat & $200{ }^{\circ} \mathrm{C}$ \\
\hline
\end{tabular}

\section{Results and discussion}

\subsection{Method optimization}

As desolvating temperature of USN was increased, the effect of sorbitol was decreased during the optimization step. However, while condensing temperature of USN was increasing, the effect of sorbitol was also increased. Different amounts of sorbitol were used in order to determine the most suitable amount and most suitable temperatures for USN.

\subsection{Optimization the amount of sorbitol}

Solutions containing $0 \% ; 0.05 \% ; 0.1 \% ; 0.25 \% ; 0.5 \% ; 0.75 \%$; and $1 \%$ sorbitol and $1 \mathrm{mg} \mathrm{L}^{-1}$ Boron were prepared respectively. They were analyzed by ICP-OES and the results are displayed in Figure 1. 


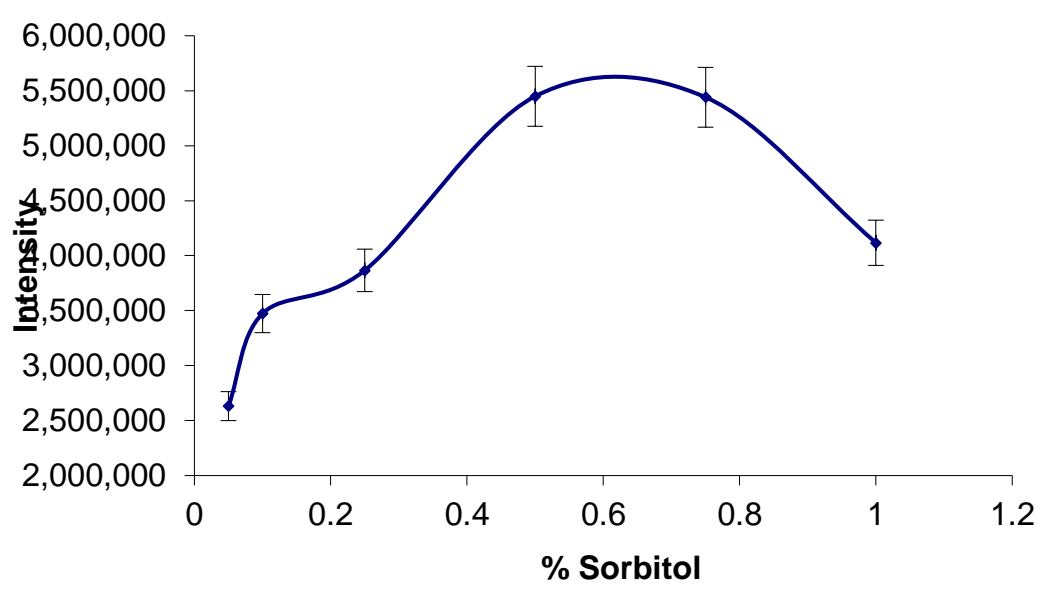

Figure1. Optimization of the amount of Sorbitol

\subsection{Optimization of USN temperature}

There are two kinds of temperature in USN system; these are desolvating and condensing temperature. $1.00 \mathrm{mg} \mathrm{L}^{-1}$ standard solution of Boron containing $0.5 \%$ sorbitol was analyzed at five different desolvating temperature $120^{\circ} \mathrm{C} ; 130^{\circ} \mathrm{C} ; 140^{\circ} \mathrm{C} ; 150^{\circ} \mathrm{C}$; and $160^{\circ} \mathrm{C}$, respectively and the results are displayed in Figure 2.

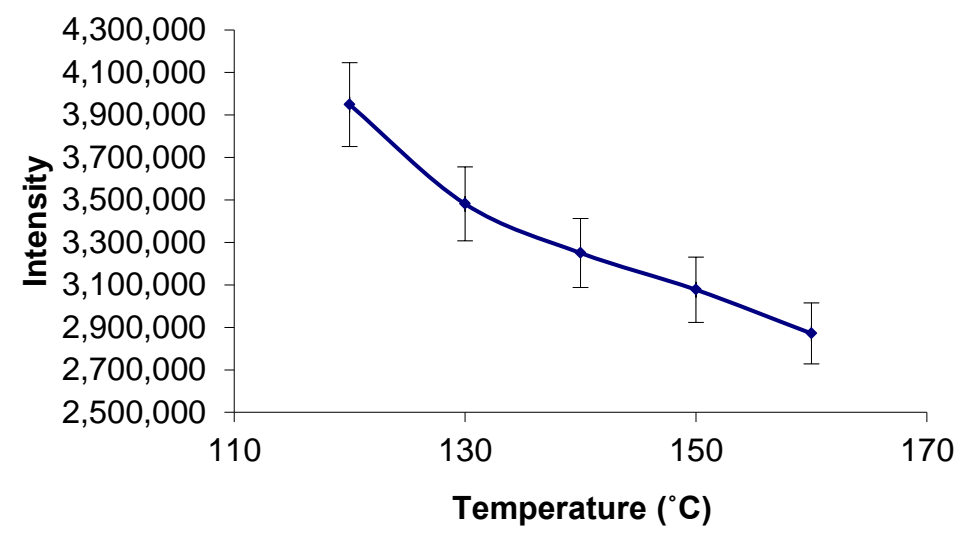

Figure 2. Optimization of desolvating temperature

It was found that $120^{\circ} \mathrm{C}$ is suitable as desolvating temperature. $1.00 \mathrm{mg} \mathrm{L}^{-1}$ standard solution of Boron containing $0.5 \%$ sorbitol was analyzed at five different condensing temperatures $2^{\circ} \mathrm{C} ; 4^{\circ} \mathrm{C} ; 6^{\circ} \mathrm{C}$; $8^{\circ} \mathrm{C} ; 10^{\circ} \mathrm{C}$, respectively and the results are displayed in Figure 3. It was found that $10^{\circ} \mathrm{C}$ is suitable as condensing temperature. 


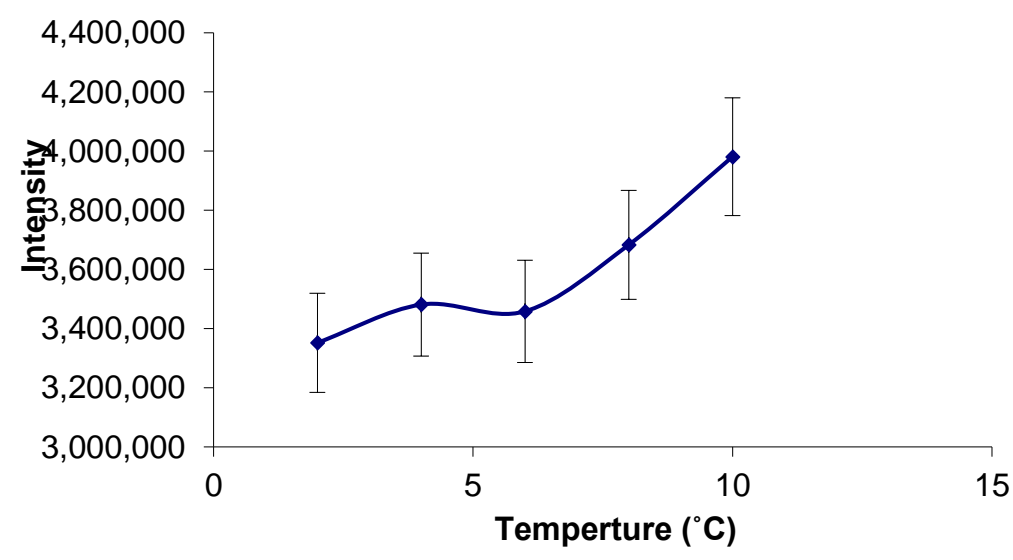

Figure 3. Optimization of condensing temperature

\subsection{The memory effect of boron}

The memory effect is a major problem for determination of Boron by using ICP-OES and USN. Memory effect is formed by reaction of Boron with the glass walls of aerosol chamber and by condensing and desolvating tubes. Boron binds the glass wall, therefore Boron signals decrease $[6,9]$.

USN was used to provide sufficient sensitivity instead of a typical pneumatic nebulizer which do not have sufficient sensitivity to detect low concentrations of Boron and memory effect occurs with using USN. Sorbitol therefore was used to reduce memory effects.

\subsection{Sample analysis}

Hazelnuts, soils, and CRM containing $0.5 \%$ sorbitol were analyzed with ICP-OES and USN at $249.773 \mathrm{~nm}$. The USN condensing temperature and desolvating temperature were set $10{ }^{\circ} \mathrm{C}$ and $120{ }^{\circ} \mathrm{C}$, respectively. Blank solutions were prepared without sample. All samples were analyzed with three replicates and blanks were analyzed with ten replicates. Table 4, Table 5 and Table 6 show the Boron content of hazelnut samples, soil samples and CRM, respectively.

Table 4. Boron content of hazelnut samples ( $\mathrm{mg} / \mathrm{kg} \pm \mathrm{RSD} \%)$

\begin{tabular}{cccc}
\hline Hazelnut Variety & Boron content & \multicolumn{2}{c}{ Boron content } \\
\hline & Our Results & Others $^{[2]}$ & Others $^{[22]}$ \\
\cline { 2 - 4 } Delisava (Çak1ldak) & $38.6 \pm 1.8$ & 16.8 & 14.28 \\
Kara & $18.2 \pm 0.7$ & 17.8 & 13.31 \\
Sivri & $28.3 \pm 0.6$ & 15.7 & 17.27 \\
Tombul & $17.6 \pm 1.0$ & 17.3 & 13.63 \\
\hline
\end{tabular}

The hazelnut samples among the varieties of Delisava and Sivri from Ferizli, and Kara and Tombul from Yanıkköy-Sapanca were analyzed according to results of the method optimization. Furthermore, the soil samples were analyzed with the same method.

The results of Boron content in hazelnut varieties are given in Table 4. Simsek et al. [5] studied Boron content of hazelnut varieties by using ICP-OES. The results were varied between $15.7 \mathrm{mg} / \mathrm{kg}$ to $16.8 \mathrm{mg} / \mathrm{kg}$ (Table 4). And also Simsek, A. \& Aykut, O. studied Boron content of hazelnuts and results are shown in Table 4 [23]. The results are between $13.31-17.27 \mathrm{mg} / \mathrm{kg}$. 
Table 5 shows the amount of Boron in soil samples which were taken from hazelnut varieties cultivated. In the literature Sun et al. studied on determination of total Boron in soils by ICP-OES using microwave digestion method and the results were found between $19.0-79.0 \mathrm{mg} / \mathrm{kg}[9]$.

Table 5. Boron content of soil samples

\begin{tabular}{ll}
\hline Soil Samples & \multicolumn{1}{c}{$\begin{array}{c}\text { Results } \\
(\mathrm{mg} / \mathrm{kg} \pm \text { RSD \%) }\end{array}$} \\
\hline Kara $(5 \mathrm{~cm})$ & $32.46 \pm 2.14$ \\
Kara $(20 \mathrm{~cm})$ & $30.44 \pm 1.18$ \\
Tombul $(5 \mathrm{~cm})$ & $196.79 \pm 10.12$ \\
Tombul $(20 \mathrm{~cm})$ & $157.68 \pm 13.45$ \\
Sivri $(5 \mathrm{~cm})$ & $38.83 \pm 2.36$ \\
Sivri $(20 \mathrm{~cm})$ & $35.90 \pm 3.14$ \\
Delisava $(5 \mathrm{~cm})$ & $49.89 \pm 1.78$ \\
Delisava $(20 \mathrm{~cm})$ & $35.06 \pm 3.65$ \\
\hline
\end{tabular}

Emiroglu et al. investigated Boron concentrations in sediment and various matrixes. Sediment samples were taken from different areas and Boron contents were found between 10.0-36.0 mg/kg [24]. Also Sungur, S. and Okur. R. studied on Boron determination in Hatay region. Boron contents of the study were found between $32.43 \mathrm{mg} / \mathrm{kg}$ and $93.43 \mathrm{mg} / \mathrm{kg}$ [25].

The differences between the present study and the literature, in terms of the Boron contents, can be explained by the differences in the geological, ecological, organic matter, and temperature and $\mathrm{pH}$ between soils, the methods used for Boron determination, and the fertilizer used for the plants [25].

\subsection{Statistical analysis}

Recovery test for Boron in Corn flour certified reference material (NIM-GBW10012) is shown in Table 6 to evaluate the reliability of the method used [26, 27].

Table 6. Boron content of CRM ( $\mathrm{mg} / \mathrm{kg} \pm \mathrm{RSD} \%)$.

\begin{tabular}{llll}
\hline CRM & Our Value & CRM value & Recovery\% \\
\hline Corn Flour $^{(a)}$ & $0.88 \pm 0.12$ & $0.86 \pm 0.11$ & 102.3 \\
\hline
\end{tabular}

(a) NIM-GBW10012 corn flour certified reference material

\section{Conclusions}

All of the results showed that sorbitol influences memory effect in a positive way and it has been observed that the memory effect of Boron was decreased with the use of sorbitol. When different condensing and desolvating temperatures were applied in USN, different signal intensities of ICP-OES were observed. The signal intensity of ICP-OES was affected by different concentrations of Sorbitol. The results showed that hazelnut varieties and soil samples have rich Boron contents. The Boron content of hazelnut varieties is highest in Delisava and Tombul variety is of the lowest quantity. When the soil samples were analyzed it was seen that Tombul hazelnut variety is rich in Boron content. 
The memory effect is a major problem for determination of Boron by using ICP-OES and USN. It is formed by reaction of Boron with the glass walls of aerosol chamber and by condensing and desolvating tubes. Memory effect of Boron occurs while using Ultrasonic Nebulizer, and therefore Sorbitol was used to reduce memory effects.

The analytical sensitivity of Boron was notably enhanced and the memory effects were significantly reduced in ICP-OES with an ultrasonic nebulizer and the addition of mannitol.

\section{Acknowledgements}

This study was supported by Commission of Sakarya University Scientific Research Projects (Project No: 2012-50-01-022).

\section{ORCID}

Mustafa Sahin Dündar: 0000-0002-5117-7864

Huseyin Altundağ: 0000-0002-3675-4133

Gülşah Tunca: 0000-0001-7423-7877

\section{References}

[1] F. Ozdemir and I. Akınc1 (2003). Physical and nutritional properties of four major commercial turkish hazelnut varieties, J. Food Eng. 63, 341-347.

[2]. F. Ozkutlu, Y. Z. Dogru, N. Ozenç, G. Yazıcı, M. Turan and F. Akçay (2010). The importance of Turkish hazelnut trace and heavy metal contents for human nutrition, J. Soil Sci. Environ. Ma. 2, 25-33.

[3] A. I. Koksal, N. Artik, A. Simsek and N. Guneş (2005). Nutrient composition of hazelnut (Coryus Avella L.) varieties cultivated in Turkey, Food Chem. 99, 509-515.

[4] U. Cevik, A. Celik, N. Damla and K. Coskunelebi (2009). Radioactivity and heavy metal levels in hazelnut growing in the Eastern Black Sea region of Turkey, Food Chem. Toxicol. 47, 2351-2355.

[5] A. Simsek, D. Korkmaz, Y. S. Velioglu and O. Y. Ataman (2003). Determination of boron in hazelnut (Corylus Avella L.) varieties by inductively coupled plasma optical emission spectrometry and spectrophotometry, Food Chem. 83, 293-296.

[6] D. H. Sun, J. K. Waters and T. P. Mawhinney (1997). Microwave digestion and ultrasonic nebulization for determination of boron in animal tissues by inductively coupled plasma atomic emission spectrometry with internal standardization and addition of mannitol, J. Anal. Atom.Spectrom. 12, 675-679.

[7] S. Bakirdere, S. Orenay and M. Korkmaz (2010). Effect of boron on human health, Open Mineral Process. J. 3,54-59.

[8] A. Krejčová and T. Ćernohorský (2003). The determination of boron in tea and coffee by ICP-AES method, Food Chem. 2, 303-308.

[9] D. H. Sun, J. K. Waters and T. P. Mawhinney (1998). Determination total boron in soils by inductively coupled plasma atomic emission spectrometry using microwave assisted digestion, Commun. Soil Sci. Plan. 29, 2493-2503.

[10] S. Evans and U. Krähenbühl (1994). Improved boron determination in biological material by inductively coupled plasma mass spectrometry, J. Anal. Atom. Spectrom. 9, 1249-1252.

[11] R. N. Sah and P. H. Brown (1997). Techniques for boron determination and their application to the analysis of plant and soil samples, Plant Soil. 193, 15-33.

[12] R. N. Sah and P. H. Brown (1997). Boron determination - A review of analytical methods, Microchem. J. 56, 285-304.

[13] S. P. Dolan and S. Capar (2002). Multi-element analysis of food by microwave digestion and inductively coupled plasma-atomic emission spectrometry, J. Food Compos. Anal. 15, 593-615.

[14] C. J. Warren, B. Xng and M. J. Dudas (1990). Simple microwave digestion technique for elemental analysis of mineral soil samples, Can. J. Soil Sci. 70, 67-620

[15] D. H. Sun, J. K. Waters and T. P. Mawhinney (2000). Determination of thirteen common elements in food samples by inductively coupled plasma atomic emission spectrometry: comparison of five digestion methods, J. AOAC Int. 83, 5.

[16] H. Altundag and M. Tuzen (2011). Comparison of dry, wet and microwave digestion methods for the multi element determination in some dried fruit samples by ICP-OES, Food Chem. Toxicol. 49, 2800-2807. 
[17] S. Saracoglu, M. Tuzen and M. Soylak (2009). Evaluation of trace elements of dried apricot samples from Turkey, J. Hazard. Mater. 167, 647-652.

[18] D. O. Uluozlu, M. Tuzen, D. Mendil and M. Soylak (2008). Assessment of trace element contents of chicken products from Turkey, J. Hazard. Mater. 163, 982-987.

[19] E. Sesli, M. Tüzen and M. Soylak (2008). Evaluation of trace metal contents of some wild edible mushrooms from Black Sea region, Turkey, J. Hazard. Mater. 160, 462-467.

[20] A. M. S. Nyomora, R. N. Sah, P. H. Brown and R. O. Miller (1997). Boron determination in biological materials by inductively coupled plasma atomic emission and mass spectrometry: effect of sample dissolution methods, Fres. J. Anal. Chem. 357, 1185-1197.

[21] C. Esen and A. Balc1 (2008). Application of microwave-assisted digestion to trace heavy metal determination in sea sediment sample, J. Biol. Chem. 36, 123-128.

[22] Hakan Çelik, Murat Ali Turan, Barış Bülent Aşık, Ali Vahap Katkat (2018). Evaluation of analytical methods for boron determination in maize shoots, Commun. Soil Sci. Plan. 48(21), 2573-2581.

[23] A. Simsek and O. Aykut (2007). Evaluotion of the microelement profile of Turkish hazelnut (Corylus Avella L.) varities for human nutrition and health, Int. J. Food Sci. Nutr. 58(8), 677-688.

[24] Ö. Emiroglu, A. Cicek, N. Arslan, S. Aksan and M. Ruzgar (2010). Boron concentration in water, sediment and different organisms around large borate deposits of Turkey, B.Environ. Contam. Tox. 84, 427-431.

[25] S. Sungur and R. Okur (2009). Using azomethine-h method determination of boron contents of various foods consumed in Hatay region in Turkey, Food Chem. 115, 711-714.

[26] MathSoft Axum 4.1 Technical Graphics and Data Analysis for windows, 101 Main St. Cambridge, Massachusetts, USA, http://www.mathsoft.com.

[27] Mustafa S. Dundar and Huseyin Altundag (2004). Selenium content of Turkish hazelnut varieties: Kara fındık, Tombul and Delisava, J. Food Compos. Anal. 17, 707-712.

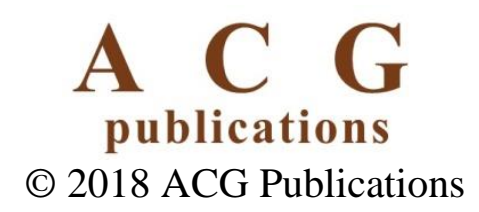

